\title{
Sistem Rekomendasi untuk Optimalisasi Pemilihan Petak Makam di TPU menggunakan Metode Simple Additive Weighting Berbasis Web
}

\author{
Alfi Nurfazri ${ }^{[1]}$, Naldi Nashih Ulwan ${ }^{[2]}$, Rinto Priambodo ${ }^{[3]^{*}}$ \\ Fakultas Ilmu Komputer Program Studi Sistem Informasi [1], [2], [3] \\ Universitas Mercu Buana \\ Jakarta Barat, Indonesia \\ 41816010007@student.mercubuana.ac.id ${ }^{[1]}, 41816010064 @$ student.mercubuana.ac.id ${ }^{[2]}$, \\ rinto.priambodo@mercubuana.ac.id ${ }^{[3]}$
}

\begin{abstract}
In life, there is also death, every day the number of people who are born in the world continues to increase followed by the death of a person. The death rate in DKI Jakarta in early 2020 was 3,072 reports and then there was a significant increase in February as many as 5,792 reports. Public Cemetery is an area of land provided for funeral purposes for any person regardless of religion and class. The City Parks and Forests Service of the Provincial Government of the Special Capital Region of Jakarta is a Regional Work Unit in charge of Forestry, Landscaping, and Cemeteries in the DKI Jakarta Regional Work Scope. The amount of time and energy needed in the funeral process for a corpse in DKI Jakarta Province starts from registering the body, selecting the location to the heir to obtain an IPTM from the PTSP. While the burial process must be carried out quickly, especially in certain conditions, such as during the pandemic, where the bodies must be buried immediately and the limited burial ground available. This recommendation system aims to simplify the process of registering bodies, selecting the cemetery, selecting plots, and managing tombs. By using the SAW method in the selection of cemeteries and grave plots, it will optimize burial plots by selecting the best alternative based on predetermined criteria so that it will reduce TPU cases of fullness or unavailability of grave plots.
\end{abstract}

Keywords- Public Cemeteries, Recommendation Systems, Simple Additive Weighting Methods, City Parks and Forests Service, Provincial Government of the Special Capital Region of Jakarta

Abstrak - Di dalam kehidupan pasti juga ada kematian, setiap hari jumlah orang yang terlahir di dunia terus bertambah diikuti dengan kematian seseorang. Angka kematian di DKI Jakarta pada awal tahun 2020 sebanyak 3.072 pelaporan dan kemudian terjadi peningkatan yang signifikan pada bulan Februari sebanyak 5.792 pelaporan. Tempat Pemakaman Umum adalah areal tanah yang disediakan untuk keperluan pemakaman jenazah bagi setiap orang tanpa membedakan agama dan golongan. Dinas Pertamanan Dan Hutan Kota Pemerintah Provinsi Daerah Khusus Ibukota Jakarta merupakan Satuan Kerja Perangkat Daerah yang mengurusi urusan Kehutanan, Pertamanan, dan Pemakaman di Lingkup Kerja Wilayah DKI Jakarta. Banyaknya waktu dan tenaga yang dibutuhkan dalam proses pemakaman jenazah di Provinsi DKI Jakarta mulai dari pendaftaran jenazah, pemilihan lokasi sampai oleh ahli waris hingga mendapatkan IPTM dari PTSP. Sementara proses pemakaman harus dilakukan dengan cepat terutama pada kondisi tertentu seperti dalam masa pandemi di mana jenazah harus segera dimakamkan dan serta terbatasnya lahan pemakaman yang tersedia. Sistem rekomendasi ini bertujuan untuk mempermudah proses pendaftaran jenazah, pemilihan TPU, pemilihan petak dan juga pengelolaan makam. Dengan menggunakan metode SAW dalam pemilihan TPU dan petak makam akan mengoptimalkan petak pemakaman dengan memilih alternatif terbaik berdasarkan kriteria-kriteria yang sudah ditentukan sehingga akan mengurangi kasus TPU kepenuhan atau tidak tersedianya petak makam.

Kata Kunci-Tempat Pemakaman Umum, Sistem Rekomendasi, Metode Simple Additive Weighting, Dinas Pertamanan Dan Hutan Kota Pemerintah Provinsi Daerah Khusus Ibukota Jakarta

\section{PENDAHULUAN}

Perkembangan zaman yang semakin meningkat dengan diiringinya perkembangan teknologi. Sehingga, semua bidang dalam kehidupan sehari - hari memerlukan dukungan teknologi yang dapat membantu pekerjaan menjadi lebih efektif dan efisien.

Di dalam kehidupan pasti juga ada kematian, setiap hari jumlah orang yang terlahir di dunia terus bertambah diikuti dengan kematian seseorang. Angka kematian di DKI Jakarta pada awal tahun 2020 sebanyak 3.072 pelaporan dan kemudian terjadi peningkatan yang signifikan pada bulan Februari sebanyak 5.792 pelaporan [1]. Tidak ada yang tahu kapan kematian akan terjadi, saat seseorang meninggal kita pasti perlu menyiapkan pemakaman secepatnya dan muncul pertanyaan seperti di mana tempat akan dimakamkan, kapan waktu dimakamkan. Terutama di masa pandemi di mana banyak ditemui kondisi jenazah harus segera dimakamkan.

Makam merupakan bangunan dari tanah bata, batu dan kayu untuk memberi tanda pada tempat itu bahwa ada jenazah yang dikubur di bawahnya [2]. Pemakaman adalah serangkaian kegiatan yang meliputi kegiatan administrasi pemakaman, pengaturan lokasi makam, koordinasi dan pemberian bimbingan atau petunjuk serta pengawasan terhadap pelaksanaan pemakaman [3]. Sementara itu ahli waris merupakan orang yang melakukan pendaftaran terhadap jenazah yang akan dimakamkan, dan juga ahli waris bertanggung jawab akan pemakaman jenazah yang didaftarkan dalam hal perawatan dan pengelolaan makam [4]. 
Tempat Pemakaman Umum adalah areal tanah yang disediakan untuk keperluan pemakaman jenazah bagi setiap orang tanpa membedakan agama dan golongan, yang dikelola oleh Pemerintah Daerah Tingkat II atau Pemerintah Desa [5] [6] [7] [8].

Tempat pemakaman di Indonesia dibedakan menjadi beberapa jenis, yaitu: Tempat Pemakaman Umum (TPU) yang ditujukan untuk masyarakat umum yang penggolongannya dibedakan berdasarkan agama yang dianut. Setiap agama memiliki aturan tersendiri untuk mengatur lahan pemakaman. Pemanfaatannya sebagai lahan terbuka hijau tidak sama dalam masing-masing pemakaman. Selain itu, terdapat juga Tempat Pemakaman Khusus (TPK) yang biasanya berupa Taman Makam Pahlawan [9].

Dinas Pertamanan Dan Hutan Kota Pemerintah Provinsi Daerah Khusus Ibukota Jakarta merupakan Satuan Kerja Perangkat Daerah yang mengurusi urusan Kehutanan, Pertamanan, dan Pemakaman di Lingkup Kerja Wilayah DKI Jakarta [10].

Dinas Pertamanan Dan Hutan Kota Pemerintah Provinsi Daerah Khusus Ibukota Jakarta mempunyai tugas melaksanakan pengelolaan pertamanan dan pemakaman. Serta berfungsi merumuskan kebijakan teknis pelaksanaan pengelolaan pertamanan dan pemakaman, penyediaan tanah makam, pemetakan tanah makam, dan tata keindahan taman pemakaman umum, pelayanan, pembinaan dan pengendalian rekomendasi, perizinan, standarisasi dan / atau sertifikasi di bidang pertamanan dan pemakaman dan juga pengawasan dan pengendalian pemanfaatan makam, taman, jalur hijau, dan keindahan kota [11].

Sistem rekomendasi adalah sebuah sistem yang dapat memberikan rekomendasi kepada para pengguna sistem yang akan dibuat [12].

Berdasarkan hasil observasi sebelum dapat melakukan pemakaman di Provinsi DKI Jakarta, ahli waris harus melakukan beberapa tahapan proses seperti pendaftaran jenazah dan pemilihan petak makam. Dari segi prosedur pendaftaran ahli waris membutuhkan banyak waktu dan tenaga untuk mendapatkan IPTM juga Dinas Pertamanan Dan Hutan Kota Pemerintah Provinsi Daerah Khusus Ibukota Jakarta belum memiliki sistem rekomendasi tempat pemakaman umum di mana pengelola TPU akan memilihkan tempat pemakaman umum secara manual dan ahli waris harus mencari petak makam yang masih kosong dari segi pemilihan petak juga akan dapat menyebabkan penuhnya kapasitas pemakaman jika ahli waris dibebaskan memilih tanpa adanya kriteria atau syarat tertentu. Belum lagi tidak adanya sistem yang dapat membantu ahli waris dalam pengelolaan informasi makam yang dipunya.

Oleh sebab itu perlu adanya sistem yang dapat membantu mengoptimalkan petak pemakaman dan juga sesuai dengan tugas dan fungsi Dinas Pertamanan Dan Hutan Kota Pemerintah Provinsi Daerah Khusus Ibukota Jakarta dalam melaksanakan pengelolaan dalam bidang pemakaman maka diperlukan sistem yang dapat membantu dari segi pendaftaran, pemilihan petak makam dan pengelolaan makam baik dari pihak TPU maupun ahli waris.

\section{METODE PENELITIAN}

Metode penelitian ini dapat digambarkan berupa diagram alir seperti pada Gambar 1

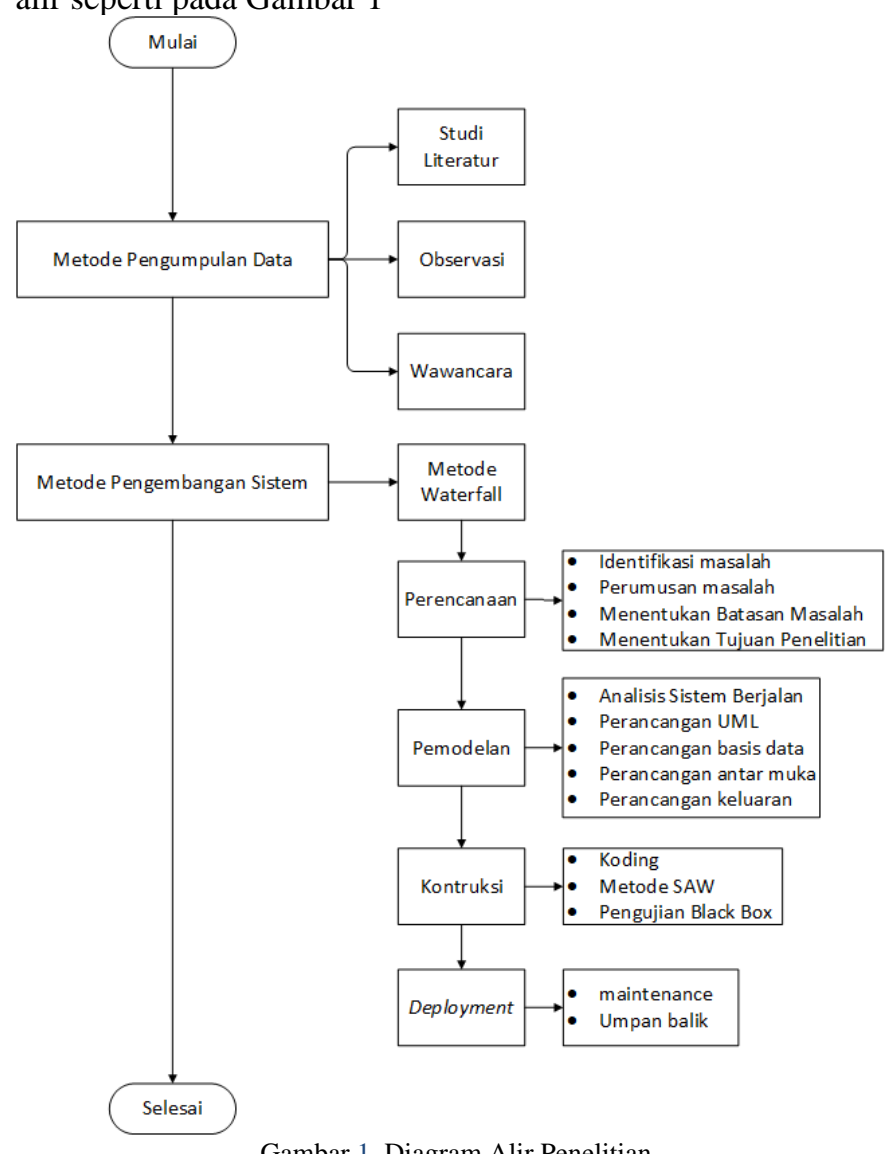

Gambar 1. Diagram Alir Penelitian

\section{A. Metode Pengumpulan Data}

Pengumpulan referensi dan data dalam penelitian ini dilakukan dengan beberapa cara. Studi Literatur, dilakukan dengan cara mencari informasi melalui jurnal, buku, dan referensi internet. Observasi, dilakukan dengan cara pengamatan ke Dinas Pertamanan Dan Hutan Kota Pemerintah Provinsi Daerah Khusus Ibukota Jakarta dengan melihat sistem yang sedang berjalan sehingga penulis dapat memperoleh data yang dapat dianalisis. Sementara itu, wawancara, dilakukan dengan cara melakukan tanya jawab kepada Kepala Subbagian Tata Usaha Pusat Data dan Informasi Dinas Pertamanan Dan Hutan Kota Pemerintah Provinsi Daerah Khusus Ibukota Jakarta dengan memberikan pertanyaan terkait sistem yang telah berjalan.

\section{B. Metode Pengembangan Sistem}

Metode pengembangan yang digunakan dalam penelitian ini adalah metode Waterfall yang merupakan metode yang sistematis dan berurutan pada pengembangan perangkat lunak, yang dimulai dengan spesifikasi kebutuhan, pengguna, dan berlanjut melalui tahapan-tahapan perencanaan (planning), 
pemodelan (modeling), konstruksi (construction), serta penyerahan sistem/perangkat lunak ke para pelanggan/pengguna (deployment) [17]. Metode Waterfall mempunyai dua keuntungan, yaitu ia mengidentifikasi spesifikasi kebutuhan sistem jauh sebelum pemrograman dimulai dan meminimalkan perubahan pada spesifikasi kebutuhan saat proyek dimulai [18].

\section{1) Perencanaan}

Melakukan perencanaan akan pelaksanaan penelitian yang terdiri dari identifikasi masalah, perumusan masalah, menentukan batasan masalah, menentukan tujuan penelitian.

Identifikasi masalah, Berdasarkan latar belakang permasalahan yang ada, maka dapat di identifikasi masalah yaitu satu sama lain berkaitan atau berhubungan. Selanjutnya proses analisa masalah yang dilakukan menggunakan metode PIECES. Identifikasi masalah menggunakan PIECES dapat dilihat dalam Tabel 1.

TABEL 1. IDENTIFIKASI MASALAH ANALISA PIECES

\begin{tabular}{|c|c|c|}
\hline & Sistem Lama & Sistem Baru \\
\hline $\begin{array}{l}\text { Performance } \\
\text { (Kinerja) }\end{array}$ & $\begin{array}{l}\text { Bekerja hanya pada saat } \\
\text { seseorang } \\
\text { menyelesaikan laporan ke } \\
\text { RT/RW, puskesmas dan } \\
\text { kelurahan. }\end{array}$ & $\begin{array}{l}\text { Dapat bekerja di mana } \\
\text { dan kapan saja asalkan } \\
\text { terhubung ke internet }\end{array}$ \\
\hline $\begin{array}{l}\text { Information } \\
\text { (Informasi) }\end{array}$ & $\begin{array}{l}\text { Kurangnya informasi tentang } \\
\text { TPU dan petak makam yang } \\
\text { tersedia }\end{array}$ & $\begin{array}{l}\text { Sistem dapat } \\
\text { memberikan informasi } \\
\text { tentang TPU dan lokasi } \\
\text { petak makam }\end{array}$ \\
\hline $\begin{array}{l}\text { Economi } \\
\text { (Ekonomi) }\end{array}$ & $\begin{array}{l}\text { Biaya sewa makam masih } \\
\text { harus dibayar di Kas Daerah }\end{array}$ & $\begin{array}{lrr}\text { Biaya sewa } & \text { makam } \\
\text { dapat di } & \text { transfer } \\
\text { langsung } & \text { dengan } \\
\text { menggunakan } & \text { ATM } \\
\text { atau M-Banking } & \\
\end{array}$ \\
\hline $\begin{array}{l}\text { Control } \\
\text { (Kontrol) }\end{array}$ & $\begin{array}{l}\text { Tidak dapat memperbarui } \\
\text { kesalahan data yang } \\
\text { dilakukan saat pendaftaran }\end{array}$ & $\begin{array}{l}\text { Mempunyai dashboard } \\
\text { user, admin, dan super } \\
\text { admin yang digunakan } \\
\text { untuk memberikan } \\
\text { informasi r dan } \\
\text { mengelola makam yang } \\
\text { dipunya }\end{array}$ \\
\hline $\begin{array}{l}\text { Efficiency } \\
\text { (Efisiensi) }\end{array}$ & $\begin{array}{l}\text { Proses pendaftaran dan } \\
\text { pemilihan petak makam } \\
\text { secara manual }\end{array}$ & $\begin{array}{l}\text { Sistem menyediakan } \\
\text { pemesanan, pendaftaran } \\
\text { dan juga pemilihan } \\
\text { lokasi petak makam } \\
\text { secara online }\end{array}$ \\
\hline $\begin{array}{l}\text { Service } \\
\text { (Pelayanan) }\end{array}$ & $\begin{array}{l}\text { Sering terjadinya pungutan } \\
\text { liar yang dilakukan oleh } \\
\text { oknum - oknum tertentu. }\end{array}$ & $\begin{array}{l}\text { Transparansi dalam } \\
\text { informasi TPU }\end{array}$ \\
\hline
\end{tabular}

Perumusan masalah, dari latar belakang di atas dapat disimpulkan masalah yang muncul. Masalah pertama adalah bagaimana cara membuat sistem yang dapat mempercepat proses pendaftaran makam tanpa melalui proses yang rumit dan panjang serta dapat menghemat waktu. Bagaimana cara membuat sistem dapat mengoptimalkan pemilihan petak makam. Bagaimana membuat sistem yang dapat membantu pihak pengelola TPU dan juga pihak ahli waris dalam pengelolaan makam. Namun mengingat banyaknya perkembangan yang bisa ditemukan dalam permasalahan, maka perlu adanya batasan-batasan masalah yang jelas mengenai apa yang dibuat dan diselesaikan dalam penelitian ini, yaitu berfokus dalam membahas pendaftaran, pembuatan rekomendasi untuk lokasi petak makam TPU dan sistem informasi pemakaman.

\section{2) Pemodelan}

Melakukan analisis sistem berjalan dan membuat rancangan UML, basis data, antar muka, masukan, dan keluaran.

Analisa sistem berjalan, merupakan gambaran tentang sistem yang saat ini sedang berjalan di Dinas Pertamanan Dan Hutan Kota Pemerintah Provinsi Daerah Khusus Ibukota Jakarta pada bagian bidang pemakaman, penulis akan membahas bagaimana proses bisnis untuk pendaftaran pemakaman. Analisis Proses Bisnis, Pada Gambar 2 merupakan penjelasan tentang Analisa proses bisnis yang sedang berjalan menurut aktivitas di Dinas Pertamanan dan Hutan Kota Pemerintah Provinsi Daerah Khusus Ibukota Jakarta.

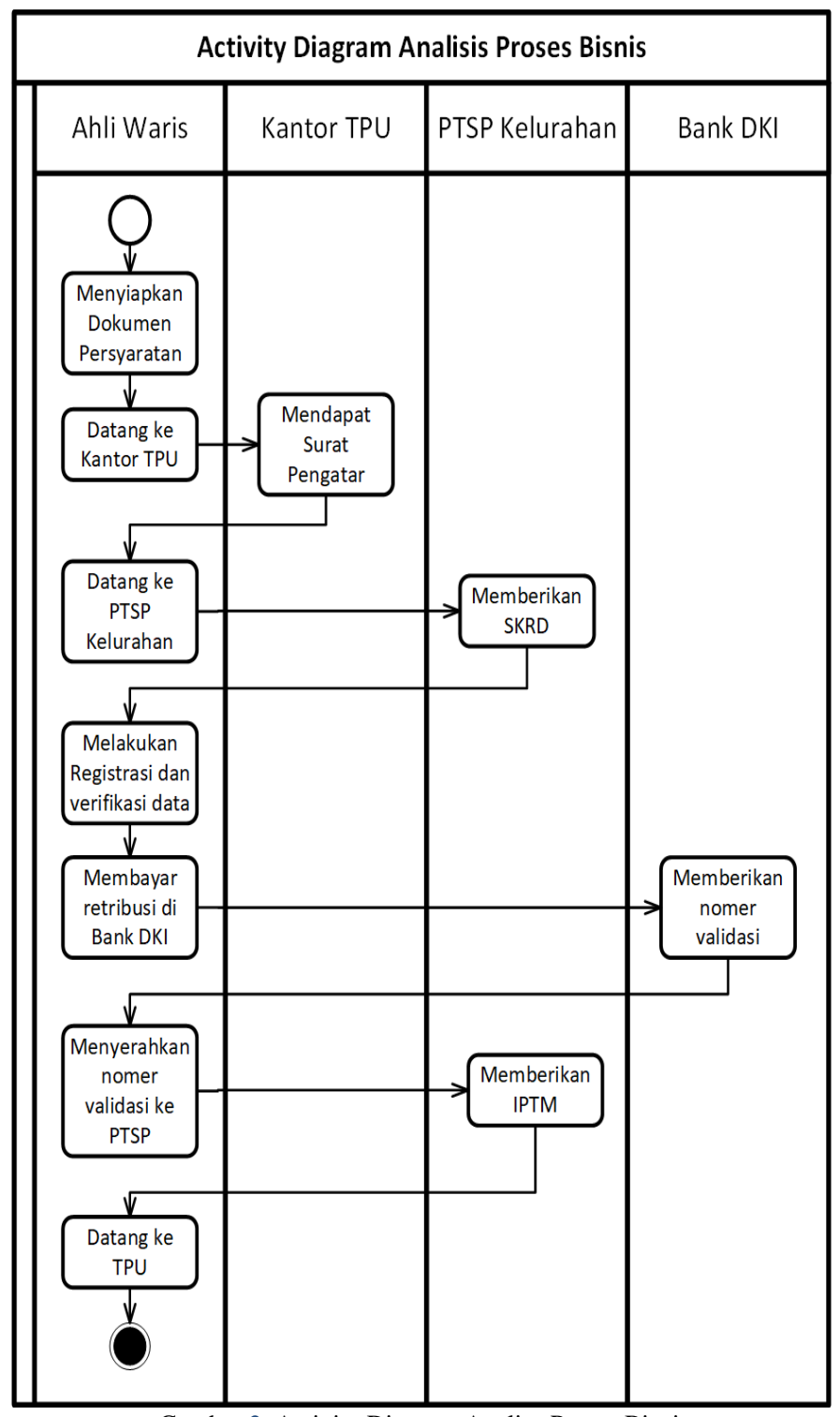

Gambar 2. Activity Diagram Analisa Proses Bisnis 
Pertama, ahli waris harus menyiapkan beberapa dokumen seperti KTP dan KK ahli waris/pemohon, KTP dan KK almarhum, surat pengantar kelurahan, surat pemeriksaan jenazah dari RS/Puskesmas, dan surat keterangan kematian dari Kelurahan. Setelah itu datang ke Kantor TPU dan ahli waris akan mendapatkan surat pengantar ke PTSP Kelurahan. Langkah berikutnya adalah mendatangi PTSP Kelurahan untuk memperoleh SKRD (Surat Ketetapan Retribusi Daerah). Ahli waris bisa melakukan registrasi dan verifikasi data di PTSP Kelurahan tersebut.

Kemudian, ahli waris harus melakukan pembayaran retribusi yang dilakukan di Bank DKI. Ahli waris akan diberikan nomor validasi yang harus diserahkan kembali ke PTSP untuk mendapatkan IPTM. IPTM berlaku selama tiga tahun dan dapat diperpanjang. Setelah itu, ahli waris bisa datang ke TPU untuk melakukan pemakaman.

Perancangan UML, Use case diagram sistem usulan dapat dilihat pada Gambar 3. Terdapat tiga role dalam use case ini, yaitu ahli waris, admin TPU, dan admin.

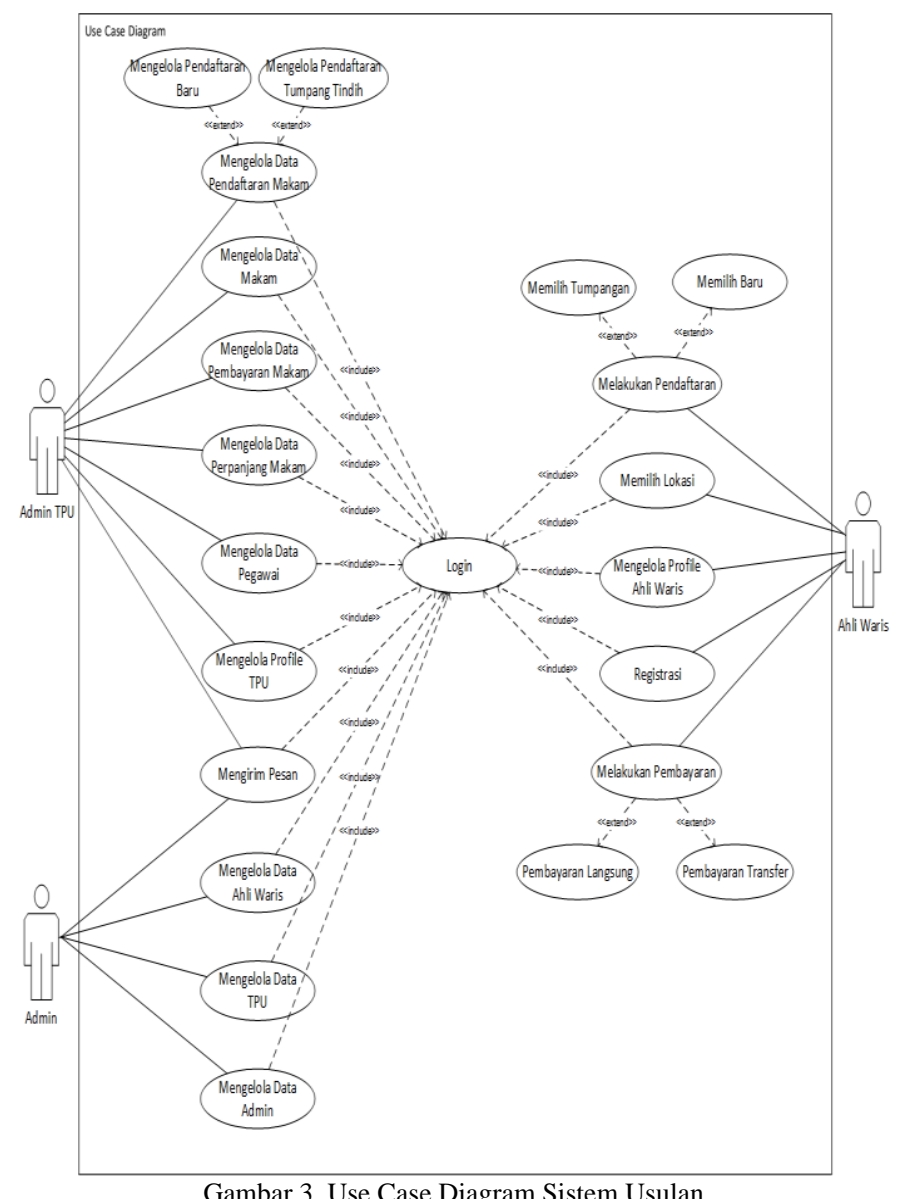

Perancangan basis data, Class diagram sistem usulan dapat dilihat pada Gambar 4. Informasi mengenai kriteria dan pembobotan yang digunakan dalam perhitungan SAW tersimpan dalam class daftar, TPU, dan lokasi.

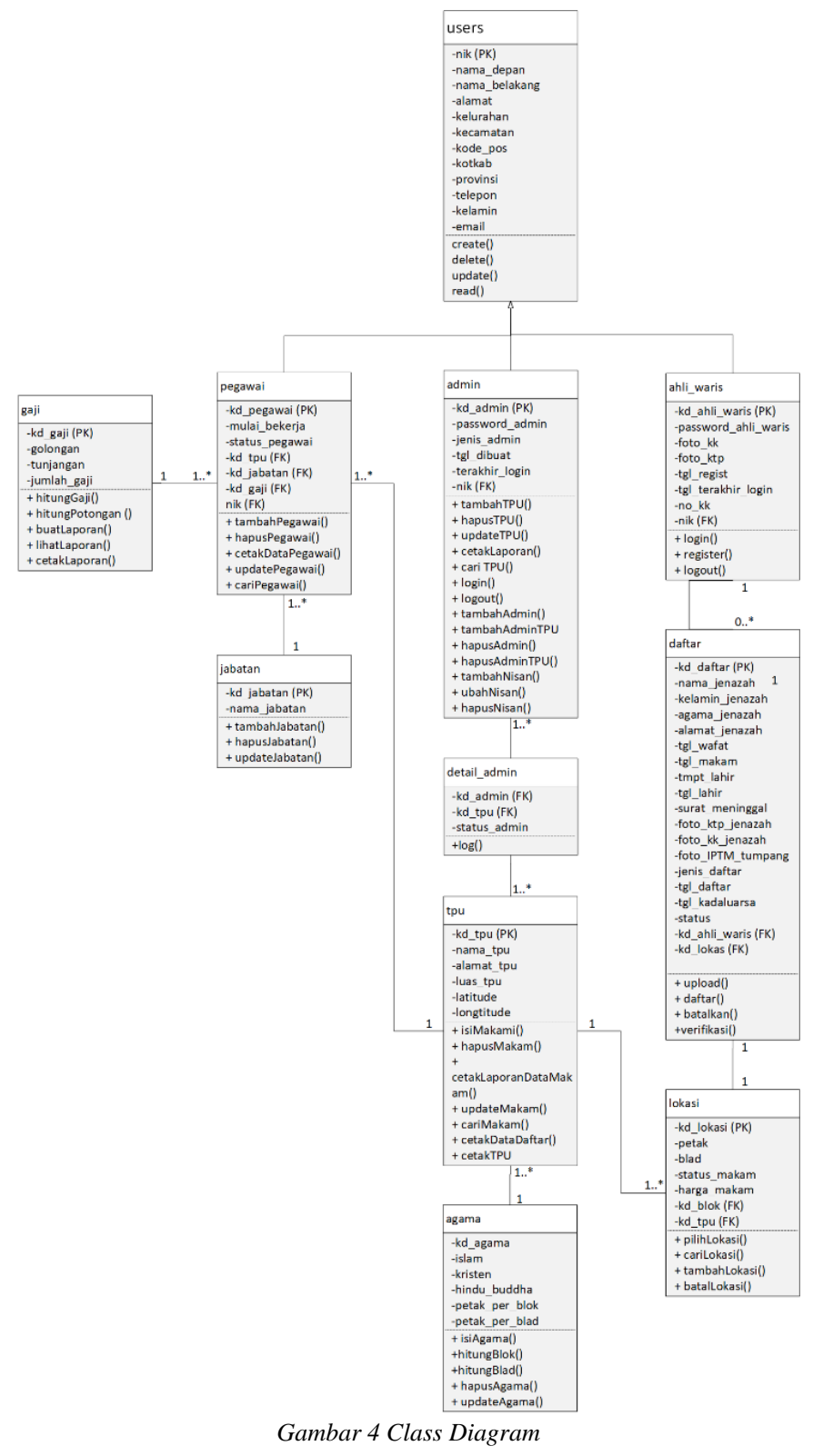

Merancang antar muka sistem yang akan digunakan oleh user. Hasil dari perancangan antarmuka akan menjadi tampilan antarmuka sistem yang dapat dilihat pada gambar 5, gambar 6, gambar 7, dan gambar 8 .

Membuat perancangan yang menghasilkan informasi sesuai kebutuhan pada user.

\section{3) Metode $S A W$}

Untuk menentukan rekomendasi sistem dapat menggunakan metode Simple Additive Weighting (SAW), metode SAW adalah metode penjumlahan bobot dari kinerja setiap objek-objek yang berbeda dan memiliki kesempatan yang sama pada semua kriteria yang dimiliki. Metode SAW memerlukan proses normalisasi matriks keputusan (X) ke suatu skala yang dapat dibandingkan dengan semua alternatif peringkat yang ada [12] $[13,14,15,16]$. 
Adapun langkah penyelesaian dalam menggunakan metode SAW adalah:

- Menentukan alternatif, yaitu $\mathrm{A}_{\mathrm{i}}$.

- Menentukan kriteria yang akan dijadikan acuan dalam pengambilan keputusan, yaitu $\mathrm{C}_{\mathrm{j}}$.

- Memberikan nilai peringkat kecocokan setiap alternatif setiap kriteria.

- Menentukan bobot preferensi atau tingkat kepentingan (W) setiap kriteria. $\mathrm{W}=\left[\mathrm{W}_{1}, \mathrm{~W}_{2}, \mathrm{~W}_{3}, \ldots, \mathrm{W}_{\mathrm{J}}\right]$

- Membuat tabel peringkat kecocokan dari setiap alternatif pada setiap kriteria.

- Membuat matriks keputusan (X) yang dibentuk dari tabel peringkat kecocokan dari setiap alternatif pada setiap kriteria. Nilai $X$ setiap alternatif $\left(\mathrm{A}_{\mathrm{i}}\right)$ pada setiap kriteria $\left(\mathrm{C}_{\mathrm{j}}\right)$ yang sudah ditentukan, di mana, $\mathrm{i}=1,2, \ldots \mathrm{m}$ dan $\mathrm{j}=1,2, \ldots$.

- Melakukan normalisasi matriks keputusan dengan cara menghitung nilai peringkat kinerja ternormalisasi $\left(r_{i j}\right)$ dari alternatif $\mathrm{A}_{\mathrm{i}}$ pada kriteria $\mathrm{C}_{\mathrm{j}}$. Rumus yang digunakan pada metode Simple Additive Weighting yaitu:

$$
\mathrm{r}_{\mathrm{ij}}=\left\{\frac{\frac{x_{i j}}{\operatorname{Max}_{i}\left(x_{i j}\right)}}{\frac{\operatorname{Min}_{i}\left(x_{i j}\right)}{X_{i j}}}\right\}
$$

\section{Keterangan :}

$\mathrm{r}_{\mathrm{ij}}=$ nilai peringkat kinerja ternormalisasi

$\mathrm{X}_{\mathrm{ij}}=$ nilai atribut yang dimiliki dari setiap kriteria

$\operatorname{Max}_{\mathrm{i}}\left(\mathrm{X}_{\mathrm{ij}}\right)=$ nilai terbesar dari setiap kriteria

$\operatorname{Min}_{\mathrm{i}}\left(\mathrm{X}_{\mathrm{ij}}\right)=$ nilai terkecil dari setiap kriteria

Benefit $=$ jika nilai terbesar adalah terbaik

Cost $=$ jika nilai terkecil adalah terbaik

- Hasil dari nilai peringkat kinerja ternormalisasi $\left(\mathrm{r}_{\mathrm{ij}}\right)$ membentuk matriks ternormalisasi (R).

- Hasil akhir nilai preferensi $\left(\mathrm{V}_{\mathrm{i}}\right)$ diperoleh dari penjumlahan dari perkalian elemen baris matriks ternormalisasi (R) dengan bobot $(\mathrm{W})$ yang bersesuaian elemen kolom matriks (W).

$$
V_{1}=\sum_{j=1}^{n} W_{j} r_{i j}
$$

\section{Keterangan:}

$\mathrm{V}_{\mathrm{i}}=$ Nilai bobot preferensi dari setiap alternatif

$\mathrm{W}_{\mathrm{j}}=$ Nilai bobot kriteria

\section{HASIL DAN PEMBAHASAN}

A. Tampilan Antarmuka Sistem Usulan

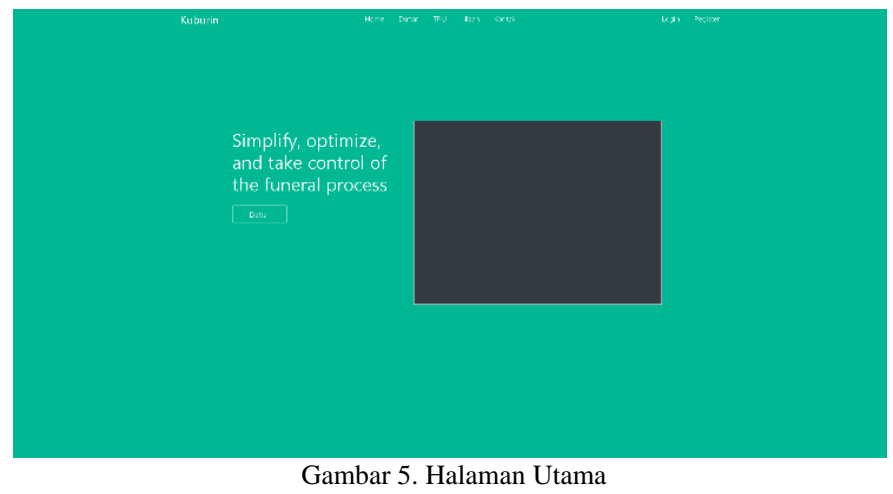

Halaman Utama, yaitu halaman yang pertama kali tampil ketika membuka web, pada bagian atas terdapat menu-menu yang dapat digunakan oleh ahli waris seperti mendaftarkan jenazah. Dapat dilihat pada Gambar 5

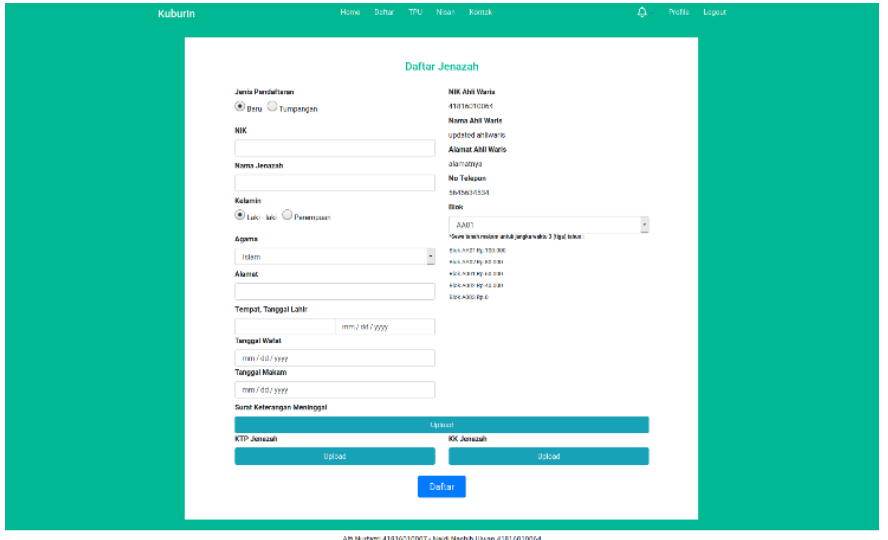

Gambar 6. Halaman Daftar Jenazah

Halaman Daftar Jenazah, yaitu halaman yang digunakan untuk mendaftarkan jenazah yang di isi oleh alih waris dan juga digunakan untuk mendapatkan peringkat kecocokan dalam metode SAW. Dapat dilihat pada Gambar 6.

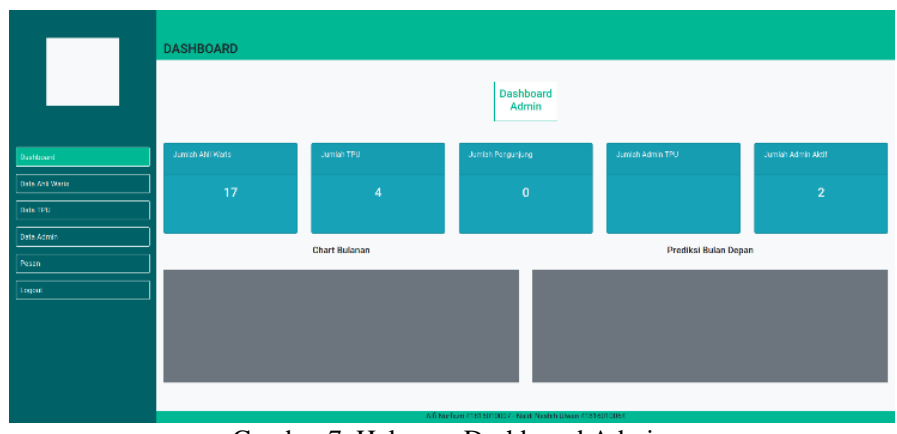

Gambar 7. Halaman Dashboard Admin

Halaman Dashboard Admin, yaitu halaman yang digunakan oleh admin untuk mengelola data. Dapat dilihat pada Gambar 7. 


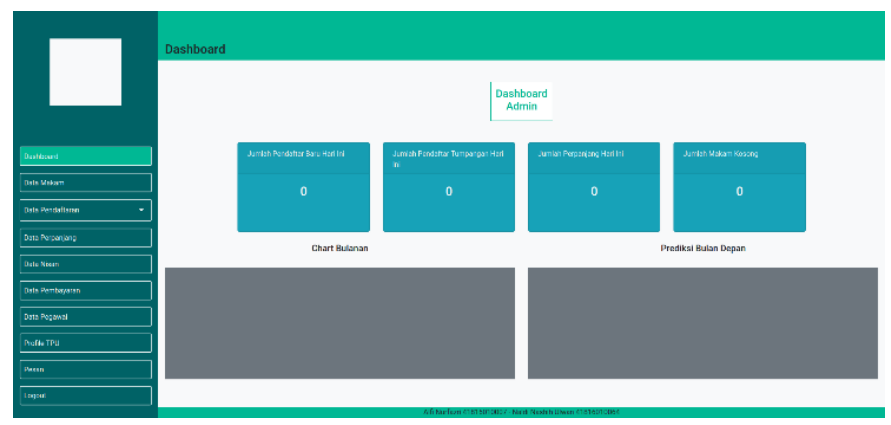

Gambar 8. Halaman Dashboard Admin TPU

Halaman Dashboard Admin TPU, yaitu halaman yang digunakan oleh Admin TPU untuk mengelola TPU. Dapat dilihat pada Gambar 8

\section{B. Metode Pengujian Blackbox}

TABEL 2. PENGUJIAN BLACKBOX

\begin{tabular}{|c|c|c|c|c|c|}
\hline $\begin{array}{l}\mathbf{N} \\
\mathbf{o}\end{array}$ & $\begin{array}{c}\text { Akto } \\
\mathbf{r}\end{array}$ & $\begin{array}{c}\text { Item } \\
\text { Pengujian }\end{array}$ & $\begin{array}{c}\text { Cara } \\
\text { Pengujian }\end{array}$ & $\begin{array}{c}\text { Hasil } \\
\text { Diharapkan }\end{array}$ & $\begin{array}{c}\text { Hasil } \\
\text { Pengujia } \\
\mathbf{n}\end{array}$ \\
\hline 1 & $\begin{array}{c}\text { Admi } \\
\text { n } \\
\text { Pusat, } \\
\text { Admi } \\
\text { n } \\
\text { TPU }\end{array}$ & $\begin{array}{l}\text { Tombol } \\
\text { Login }\end{array}$ & $\begin{array}{l}\text { 1. Masuk ke } \\
\text { URL Login } \\
\text { Admin. } \\
\text { 2. Memasukk } \\
\text { an data } \\
\text { untuk login. } \\
\text { 3. Menekan } \\
\text { Tombol } \\
\text { Login }\end{array}$ & $\begin{array}{l}\text { Menampilkan } \\
\text { halaman } \\
\text { Dashboard }\end{array}$ & Berhasil \\
\hline 2 & User & $\begin{array}{l}\text { Menu } \\
\text { Login }\end{array}$ & $\begin{array}{l}\text { Menekan } \\
\text { Menu Login } \\
\text { pada Header } \\
\text { Halaman } \\
\text { Awal }\end{array}$ & $\begin{array}{l}\text { Menampilkan } \\
\text { halaman Login } \\
\text { Ahli Waris }\end{array}$ & Berhasil \\
\hline 3 & $\begin{array}{c}\text { Ahli } \\
\text { Waris }\end{array}$ & $\begin{array}{l}\text { Tombol } \\
\text { Login }\end{array}$ & $\begin{array}{l}\text { 1. Mengisi } \\
\text { Form } \\
\text { Login. } \\
\text { 2. Menekan } \\
\text { Tombol } \\
\text { Login } \\
\text { Halaman } \\
\text { Login Ahli } \\
\text { Waris. }\end{array}$ & $\begin{array}{l}\text { 1. Mendapat } \\
\text { akses } \\
\text { terhadap } \\
\text { Ahli Waris. } \\
\text { 2. Menampilk } \\
\text { an Halaman } \\
\text { Awal }\end{array}$ & Berhasil \\
\hline 4 & $\begin{array}{l}\text { Ahli } \\
\text { Waris }\end{array}$ & $\begin{array}{l}\text { Menu } \\
\text { Daftar }\end{array}$ & $\begin{array}{l}\text { Menekan } \\
\text { Menu Daftar } \\
\text { pada Header }\end{array}$ & $\begin{array}{l}\text { Menampilkan } \\
\text { Daftar Jenazah }\end{array}$ & Berhasil \\
\hline 5 & $\begin{array}{l}\text { Ahli } \\
\text { Waris }\end{array}$ & $\begin{array}{l}\text { 1. Radio } \\
\text { Jenis } \\
\text { Pendaftara } \\
\text { n } \\
\text { 2. Mengisi } \\
\text { Form } \\
\text { Daftar } \\
\text { Jenazah } \\
\text { 3. Tombol } \\
\text { Upload } \\
\text { KTP } \\
\text { Jenazah }\end{array}$ & $\begin{array}{l}\text { 1. Menekan } \\
\text { Baru Radio } \\
\text { Jenis } \\
\text { Pendaftaran } \\
\text { 2. Mengisi } \\
\text { Form Daftar } \\
\text { Jenazah } \\
\text { 3. Menekan } \\
\text { Tombol } \\
\text { Upload Surat } \\
\text { Keterangan } \\
\text { Meninggal }\end{array}$ & $\begin{array}{l}1 . \\
\text { Mendaftarkan } \\
\text { jenazah dengan } \\
\text { jenis } \\
\text { Pendaftaran } \\
\text { Baru } \\
2 . \\
\text { Menampilkan } \\
\text { Halaman } \\
\text { Profile Ahli } \\
\text { Waris }\end{array}$ & Berhasil \\
\hline
\end{tabular}

\begin{tabular}{|c|c|c|c|c|c|}
\hline & & $\begin{array}{l}\text { 4. Tombol } \\
\text { Upload } \\
\text { KK } \\
\text { 5. Tombol } \\
\text { Daftar }\end{array}$ & $\begin{array}{l}\text { 4. Memilih } \\
\text { Foto Surat } \\
\text { Keterangan } \\
\text { Meninggal } \\
\text { 5. Menekan } \\
\text { Tombol } \\
\text { Upload KTP } \\
\text { Jenazah } \\
6 \text { 6 Memilih } \\
\text { foto KTP } \\
\text { 7. Menekan } \\
\text { Tombol } \\
\text { Upload KK } \\
\text { Jenazah } \\
\text { 8. Memilih } \\
\text { foto KK } \\
\text { 9. Menekan } \\
\text { Tombol Daftar } \\
\text { Halaman } \\
\text { Jenazah }\end{array}$ & & \\
\hline 6 & $\begin{array}{l}\text { Ahli } \\
\text { Waris }\end{array}$ & $\begin{array}{l}\text { 1. Tombol } \\
\text { Pilih } \\
\text { 2. Tombol } \\
\text { Pilih TPU }\end{array}$ & $\begin{array}{l}\text { 1. Menekan } \\
\text { Tombol Pilih } \\
\text { Halaman } \\
\text { Status } \\
\text { Pendaftaran } \\
\text { 2. Memilih } \\
\text { lokasi Ahli } \\
\text { Waris } \\
\text { 3. Menekan } \\
\text { Tombol Pilih }\end{array}$ & $\begin{array}{l}1 . \\
\text { Mendaftarkan } \\
\text { lokasi Ahli } \\
\text { Waris } \\
2 . \\
\text { Menampilkan } \\
\text { Halaman } \\
\text { Rekomendasi } \\
\text { TPU }\end{array}$ & Berhasil \\
\hline 7 & $\begin{array}{l}\text { Ahli } \\
\text { Waris }\end{array}$ & $\begin{array}{l}\text { 1. Tombol } \\
\text { Pilih } \\
\text { 2. Tombol } \\
\text { pilih TPU }\end{array}$ & $\begin{array}{l}\text { 1. Memilih } \\
\text { TPU } \\
\text { 2. Menekan } \\
\text { Tombol Pilih } \\
\text { Halaman } \\
\text { Rekomendasi } \\
\text { TPU } \\
\text { 3. Menekan } \\
\text { Tombol Pilih } \\
\text { TPU }\end{array}$ & $\begin{array}{l}\text { 1. } \\
\text { Mendaftarkan } \\
\text { Jenazah } \\
\text { dengan jenis } \\
\text { pendaftaran } \\
\text { baru ke TPU } \\
\text { yang dipilih. } \\
2 . \\
\text { Menampilkan } \\
\text { Halaman } \\
\text { Metode } \\
\text { Pembayaran }\end{array}$ & Berhasil \\
\hline
\end{tabular}

\section{Menentukan Rekomendasi Menggunakan Metode Simple Additive Weighting (SAW)}

Menentukan rekomendasi sistem menggunakan metode Simple Additive Weighting (SAW) sebagai tahap perhitungan dan diperlukan kriteria dan bobot untuk melakukan perhitungannya sehingga akan didapat alternatif terbaik.

\section{1) Menentukan Alternatif}

Adapun penilaian alternatif yang dinilai ditandai dengan A1 sampai dengan A3, dengan uraian sebagai berikut:

A1 = TPU Joglo

A2 = TPU Tanah Kusir

A3 = TPU Karet Bivak

2) Menentukan Kriteria $\left(C_{j}\right)$ yang akan dijadikan acuan rekomendasi

Metode SAW mengenal adanya 2 (dua) atribut yaitu kriteria keuntungan (benefit) dan kriteria biaya (cost) yang dibutuhkan 
untuk menentukan TPU. Kriterianya dapat dilihat dalam Tabel 3.

TABEL 3. KRITERIA

\begin{tabular}{|l|l|l|}
\hline Kriteria & Keterangan & Jenis \\
\hline C1 & Harga & Benefit \\
\hline C2 & Jarak & Benefit \\
\hline C3 & Jumlah Makam Kosong & Benefit \\
\hline
\end{tabular}

\section{3) Memberikan Nilai Peringkat Kecocokan}

Dari kriteria tersebut, maka ditentukan suatu tingkatan kepentingan kriteria berdasarkan nilai bobot yang telah ditentukan ke dalam bilangan fuzzy. Peringkat kecocokan setiap alternatif dapat dilihat dalam Tabel 4.

TABEL 4. NILAI PERINGKAT KECOCOKAN

\begin{tabular}{|l|l|}
\hline Bilangan $\boldsymbol{F u z z y}$ & Nilai \\
\hline Sangat Rendah & 1 \\
\hline Rendah & 2 \\
\hline Cukup & 3 \\
\hline Tinggi & 4 \\
\hline Sangat Tinggi & 5 \\
\hline
\end{tabular}

a) Memberikan kriteria harga petak makam TPU

Kriteria harga petak makam TPU dapat dilihat dalam Tabel 5.

TABEL 5. KRITERIA HARGA

\begin{tabular}{|l|l|}
\hline Harga & Nilai \\
\hline 100.000 & 1 \\
\hline 80.000 & 2 \\
\hline 60.000 & 3 \\
\hline 40.000 & 4 \\
\hline 0 & 5 \\
\hline
\end{tabular}

b) Memberikan kriteria jarak TPU

Kriteria jarak TPU dapat dilihat dalam Tabel 6.

TABEL 6 KRITERIA JARAK

\begin{tabular}{|l|l|}
\hline Jarak & Nilai \\
\hline$>=5 \mathrm{~km}$ & 1 \\
\hline $4 \mathrm{~km}-5 \mathrm{~km}$ & 2 \\
\hline $3 \mathrm{~km}-4 \mathrm{~km}$ & 3 \\
\hline $2 \mathrm{~km}-3 \mathrm{~km}$ & 4 \\
\hline$<=1 \mathrm{~km}$ & 5 \\
\hline
\end{tabular}

c) Memberikan kriteria jumlah makam kosong

Kriteria jumlah makam kosong dapat dilihat dalam Tabel 7.

TABEL 7 KRITERIA JUMLAH MAKAM KOSONG

\begin{tabular}{|l|l|}
\hline Jumlah Makam Kosong & Nilai \\
\hline$<100$ & 1 \\
\hline$>100$ & 2 \\
\hline$>200$ & 3 \\
\hline$>500$ & 4 \\
\hline$>1000$ & 5 \\
\hline
\end{tabular}

4) Menentukan bobot preferensi atau tingkat kepentingan (W) setiap kriteria

Pada metode Simple Additive Weighting (SAW) diberikan nilai bobot (W) berdasarkan tingkat kepentingan masingmasing kriteria yang dibutuhkan. Menentukan Nilai bobot yang di dapat diberikan pada Aplikasi Rekomendasi Tempat Pemakaman Umum dibentuk dalam Tabel 8.

TABEL 8. BOBOT PREFERENSI

\begin{tabular}{|l|l|}
\hline Kriteria (C) & Nilai \\
\hline C1 & 3 \\
\hline C2 & 4 \\
\hline C3 & 5 \\
\hline
\end{tabular}

5) Membuat tabel peringkat kecocokan

Dari setiap alternatif pada setiap kriteria dapat dilihat dalam Tabel 9.

TABEL 9. PERINGKAT KECOCOKAN

\begin{tabular}{|l|l|l|l|}
\hline Alternatif & Kriteria $(\mathbf{C j})$ & & \\
\hline & Harga $(\mathbf{C 1})$ & Jarak (C2) & $\begin{array}{l}\text { Jumlah } \\
\text { Makam } \\
\text { Kosong }(\mathbf{C 3})\end{array}$ \\
\hline A1 & 1 & 1 & 4 \\
\hline A2 & 1 & 1 & 4 \\
\hline A3 & 1 & 2 & 3 \\
\hline
\end{tabular}

6) Membuat matriks keputusan $X$

Dibentuk dari tabel peringkat kecocokan dari setiap alternatif pada setiap kriteria.

Dari Tabel 8 diubah ke dalam matriks keputusan $\mathrm{X}$ dengan data:

$$
X=\left(\begin{array}{lll}
1 & 1 & 4 \\
1 & 1 & 4 \\
1 & 2 & 3
\end{array}\right)
$$

\section{7) Melakukan normalisasi matriks keputusan}

Dengan cara menghitung nilai peringkat kinerja ternormalisasi $\left(\mathrm{r}_{\mathrm{ij}}\right.$ ) dari alternatif Ai pada kriteria $\mathrm{C}_{\mathrm{j} . \text {. Formula }}$ SAW dapat dilihat pada Persamaan 1

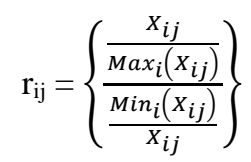

Keterangan :

$\mathrm{r}_{\mathrm{ij}} \quad=$ nilai peringkat ternormalisasi

$\mathrm{x}_{\mathrm{ij}} \quad=$ nilai atribut yang dimiliki dari setiap kriteria

$\operatorname{Max}_{\mathrm{i}} \mathrm{x}_{\mathrm{ij}}=$ nilai terbesar dari setiap kriteria

$\operatorname{Min}_{\mathrm{i}} \mathrm{x}_{\mathrm{ij}}=$ nilai terkecil dari setiap kriteria

benefit $=$ jika nilai terbesar adalah terbaik

cost = jika nilai terkecil adalah terbaik

a) Dikatakan kriteria keuntungan apabila nilai $\mathrm{x}_{\mathrm{ij}}$ memberikan keuntungan bagi pengambil keputusan, sebaliknya kriteria biaya apabila $\mathrm{x}_{\mathrm{ij}}$ menimbulkan biaya bagi pengambil keputusan.

b) Apabila berupa kriteria keuntungan maka nilai $\mathrm{x}_{\mathrm{ij}}$ dibagi dengan nilai Maxi $\left(\mathrm{x}_{\mathrm{ij}}\right)$ dari setiap kolom, sedangkan untuk kriteria biaya, nilai $\operatorname{Mini}\left(\mathrm{x}_{\mathrm{ij}}\right)$ dari setiap kolom dibagi dengan nilai $\mathrm{x}_{\mathrm{ij}}$.

Pertama-tama, dilakukan normalisasi matriks $\mathrm{X}$ berdasarkan persamaan (1) sebagai berikut: 
Untuk Harga Petak Makam

$\mathrm{r}_{11}=\frac{1}{\operatorname{Max}\{1 ; 1 ; 1\}}=\frac{1}{1}=1$

$\mathrm{r}_{21}=\frac{5}{\operatorname{Max}\{1 ; 1 ; 1\}}=\frac{1}{1}=1$

$\mathrm{r}_{31}=\frac{1}{\operatorname{Max}\{1 ; 1 ; 1\}}=\frac{1}{1}=1$

Untuk Jarak TPU

$\mathrm{r}_{12}=\frac{1}{\operatorname{Max}\{1 ; 1 ; 2\}}=\frac{1}{2}=0.5$

$\mathrm{r}_{22}=\frac{1}{\operatorname{Max}\{1 ; 1 ; 2\}}=\frac{1}{2}=0.5$

$\mathrm{r}_{32}=\frac{2}{\operatorname{Max}\{1 ; 1 ; 2\}}=\frac{2}{2}=1$

Untuk Jumlah Makam Kosong

$\mathrm{r}_{13}=\frac{4}{\operatorname{Max}\{4 ; 4 ; 3\}}=\frac{4}{4}=1$

$\mathrm{r}_{23}=\frac{4}{\operatorname{Max}\{4 ; 4 ; 3\}}=\frac{4}{4}=1$

$\mathrm{r}_{33}=\frac{5}{\operatorname{Max}\{4 ; 4 ; 3\}}=\frac{3}{4}=0.75$

8) Hasil dari nilai peringkat kinerja ternormalisasi (rij) membentuk matriks ternormalisasi $(R)$.

Matriks R:

$R=\left(\begin{array}{ccc}1 & 0.5 & 1 \\ 1 & 0.5 & 1 \\ 1 & 1 & 0.75\end{array}\right)$

9) Melakukan proses perangkingan untuk memperoleh hasil akhir nilai preferensi ( $\mathrm{Vi}$ ).

$$
V_{1}=\sum_{j=1}^{n} W_{j} r_{i j}
$$

Keterangan:

$\mathrm{V}_{\mathrm{i}}=$ Nilai bobot preferensi dari setiap alternatif

$\mathrm{W}_{\mathrm{j}}=$ Nilai bobot kriteria

$\mathrm{R}_{\mathrm{ij}}=$ Nilai peringkat kinerja

Jadi :

$$
\begin{aligned}
\mathrm{V}_{1} & =(3(1))+(4(0.5))+(5(1)) \\
& =3+2+5 \\
& =10 \\
\mathrm{~V}_{2} & =(3(1))+(4(0.5))+(5(1)) \\
& =3+2+5 \\
& =10 \\
\mathrm{~V}_{3} \quad & =(3(1))+(4(1))+(5(0.75)) \\
& =3+4+3.75 \\
& =10.75
\end{aligned}
$$

Hasil perhitungan nilai $\mathrm{V}_{\mathrm{i}}$ yang lebih besar mengindikasikan bahwa alternatif $A_{i}$ merupakan alternatif terbaik Sistem Rekomendasi Tempat Pemakaman Umum menggunakan Metode Simple Additive Weighting (SAW). Hasil penilaian terbesar ada pada $V_{3}$ yaitu TPU Karet Bivak sehingga TPU Karet Bivak layak atau dapat di jadikan alternatif dalam lokasi TPU sebagai alternatif yang terpilih sebagai alternatif terbaik.
TABEL 10. ALTERNATIF TERBAIK

\begin{tabular}{|l|l|l|l|l|l|}
\hline No & Nama TPU & $\begin{array}{l}\text { Harga } \\
\text { Petak } \\
\text { Makam }\end{array}$ & $\begin{array}{l}\text { Jarak } \\
\text { TPU }\end{array}$ & $\begin{array}{l}\text { Jumlah } \\
\text { Makam } \\
\text { Kosong }\end{array}$ & $\begin{array}{l}\text { Hasil } \\
\text { Akhir }\end{array}$ \\
\hline 1 & $\begin{array}{l}\text { TPU Karet } \\
\text { Bivak }\end{array}$ & 3 & 4 & 3.75 & 10.75 \\
\hline 2 & TPU Joglo & 3 & 2 & 5 & 10 \\
\hline 3 & $\begin{array}{l}\text { TPU Tanah } \\
\text { Kusir }\end{array}$ & 3 & 2 & 5 & 10 \\
\hline
\end{tabular}

Tabel 10 menunjukkan hasil dari pengurutan beserta besarnya hasil akhir nilai preferensi yang diperoleh dari perhitungan perkalian bobot kriteria dengan matriks hasil normalisasi. Hasil yang diperoleh akan dibandingkan dengan nilai yang dihasilkan oleh aplikasi yang ditunjukkan pada Gambar 9 Hasil Rekomendasi SAW.

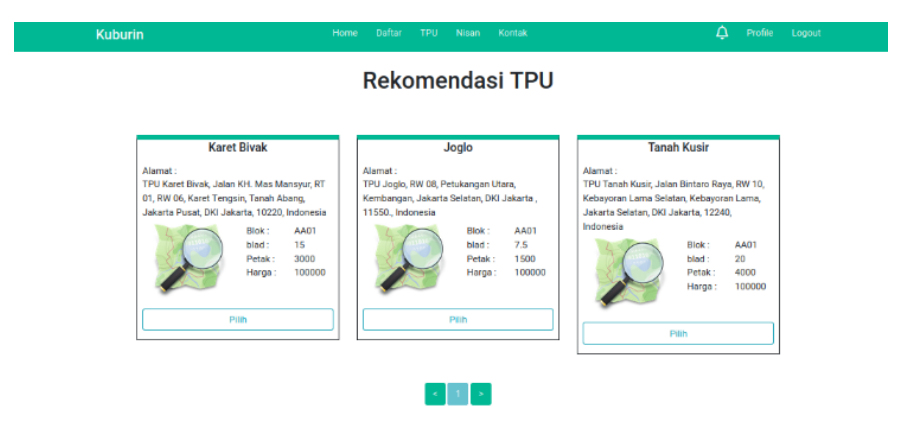

Gambar 9. Hasil Rekomendasi Menggunakan Metode SAW

Gambar 9 merupakan hasil pengurutan nilai preferensi pada aplikasi. Hasil menunjukkan angka preferensi dan urutan yang sama dengan metode perhitungan manual. Hal ini membuktikan bahwa penerapan metode SAW pada sistem telah berjalan dengan benar dan sesuai.

\section{KESIMPULAN}

Berdasarkan hasil penelitian ini, maka peneliti dapat mengambil kesimpulan dengan sistem pendaftaran secara daring tentu dapat mempersingkat waktu yang dibutuhkan untuk mendaftar dikarenakan dengan adanya sistem yang daring ahli waris tidak perlu datang ke sejumlah TPU untuk mencari lokasi yang tepat dan persyaratan pendaftaran ahli waris dapat mudah diketahui dan dipenuhi sehingga menyelesaikan masalah pendaftaran yang rumit dan panjang.

Metode SAW yang digunakan dalam pemilihan lokasi TPU dapat mengoptimalkan petak makam dikarenakan metode SAW mencari alternatif TPU yang sesuai dengan kriteria jenazah dan TPU. Selain itu sistem rekomendasi ini tidak hanya memfasilitasi pendaftaran dan pemilihan lokasi saja tapi juga berbentuk sistem informasi yang memungkinkan ahli waris untuk ikut mengelola makam yang dipunya sehingga bukan hanya pengelola TPU saja.

Untuk penelitian berikutnya, disarankan untuk membuat sistem pemakaman yang terintegrasi dengan sistem PTSP yang 
ada di Jakarta juga sistem yang dapat memprediksi jumlah angka kematian tiap bulan agar lebih dapat membantu dalam mengoptimalkan pemakaman dan melakukan pengembangan menjadi aplikasi Android atau IOS.

\section{REFERENSI}

[1] A. Irawan, "Portal Statistik Sektoral Provinsi DKI Jakartaa," Unit Pengelola Statistik, 2 Juni 2020. [Online]. Available: http://statistik.jakarta.go.id/pelaporan-kematian-periode-januaridesember-2019-dan-januari-april-2020-di-provinsi-dki-jakarta/. [Diakses 18 Oktober 2020].

[2] Y. S. Padang, L. Sumaryanti dan Y. Kolyaan, "SISTEM INFORMASI TEMPAT PEMAKAMAN UMUM TANAH MIRING KABUPATEN MERAUKE BERBASIS WEB," Musamus Journal Of Research Information and Communications Technology, vol. 1, no. 1, pp. 18-29, 2018.

[3] Restiana, L. Rifani dan I. Inayati, "Sistem Pemesanan Lahan dan Jasa Kebersihan Makam Berbasis Web (Studi Kasus : Tempat Pemakaman Umum Keputih)," Jurnal Universitas Narotama Surabaya, vol. 1, no. 1, pp. 1-9, 2015.

[4] I. Rusdi, I. F. Widy dan H. Husein, "Rancang Bangun Sistem Informasi Tempat Pemakamam Umum Pondok Rajeg Bogor," Jurnal Teknik Komputer Amik BSI, vol. V, no. 2, pp. 219-226, 2019.

[5] Frieyadie dan T. Kristiana, "Rancang Bangun Sistem Informasi Administrasi Tempat Pemakaman Umum (TPU)," Konferensi Nasional Ilmu Pengetahuan Dan Teknologi, vol. 2, no. 1, pp. 63-68, 2016.

[6] Z. Mazalisa dan Irwansyah, "SISTIM INFORMASI GEOGRAFIS TEMPAT PEMAKAMAN UMUM (TPU) DI WILAYAH KOTA PALEMBANG," Jurnal Ilmiah MATRIK, vol. 18, no. 3, pp. 271-280, 2016

[7] H. R. Hatta, M. Rizaldi dan D. M. Khairina, "Penerapan Metode Weighted Product Untuk Pemilihan Lokasi Lahan Baru Pemakaman Muslim Dengan Visualisasi Google Maps," Jurnal TEKNOSI, vol. 2, no. 3, pp. 85-94, 2016.

[8] A. S. Aji, A. Suprayogi dan A. P. Wijaya, "ANALISIS KESESUAIAN KAWASAN PERUNTUKAN PEMAKAMAN UMUM BARU BERBASIS SISTEM INFORMASI GEOGRAFIS (SIG) (Studi Kasus : Kecamatan Tembalang, Kota Semarang)," Jurnal Geodesi Undip, vol. 4, no. 3, pp. 99-107, 2015.

[9] A. Wulandari, "Kajian Potensi Pemakaman sebagai Ruang Terbuka Hijau Perkotaan," Langkau Betang Jurnal Arsitektur, vol. 1, no. 2, pp. 54-64, 2014.

[10] GUBERNUR PROVINSI DAERAH KHUSUS IBUKOTA JAKARTA, "PERATURAN GUBERNUR PROVINSI DAERAH KHUSUS IBUKOTA JAKARTA NOMOR 157 TAHUN 2019 TENTANG ORGANISASI DAN TATA KERJA DINAS PERTAMANAN DAN HUTAN KOTA,” 2019. [Online]. Available: https://pertamananpemakaman.jakarta.go.id/assets/data/dataperaturan/PERGUB-157_TAHUN_2019-TENTANGSOTK_DINAS_PERTAMANAN_DAN_HUTAN_KOTA.pdf. [Diakses 2703 2020]

[11] Admin, "Tugas Pokok dan Fungsi," Dinas Pertamanan dan Hutan Kota Provinsi DKI Jakarta, [Online]. Available: https://pertamananpemakaman.jakarta.go.id/v140/t8/4/tugas-pokok-danfungsi. [Accessed 27 Maret 2020].

[12] S. N. Rochmawati dan F. Marisa, "Sistem Rekomendasi Rumah Berbasis Web Menggunakan Metode SAW pada PT. Inproperty," Journal of Information Technology and Computer Science, vol. 3, no. 2, pp. 95-98, 2018.

[13] N. Hasanah dan R. Priambodo, "PERANCANGAN SISTEM PENDUKUNG KEPUTUSAN PRIORITAS PROGRAM KERJA DENGAN METODE SIMPLE ADDITIVE WEIGHTING (SAW)," Jurnal Cendikia, vol. XVIII, pp. 349-358, 2019.
[14] E. Daniati, "SISTEM PENDUKUNG KEPUTUSAN PEMILIHAN KOST DI SEKITAR KAMPUS UNP KEDIRI MENGGUNAKAN METODE SIMPLE ADDITIVE WEIGHTING (SAW)," Seminar Nasional Teknologi Informasi dan Multimedia, vol. 2, no. 2, pp. 145-150, 2015.

[15] F. A. Purnomo, E. H. Prastisto dan A. Z. Nurrizqi, "SISTEM REKOMENDASI PENCARIAN KEAHLIAN MAHASISWA BERDASARKAN CURRICULUM VITTAE DENGAN METODE SIMPLE ADDITVE WEIGHTING (SAW)," Indonesian Journal of Applied Informatics, vol. 2, no. 2, pp. 107-117, 2018.

[16] D. Darmastuti, "IMPLEMENTASI METODE SIMPLE ADDITIVE WEIGHTING (SAW) DALAM SISTEM INFORMASI LOWONGAN KERJA BERBASIS WEB UNTUK REKOMENDASI PENCARI KERJA TERBAIK," Jurnal Sistem dan Teknologi Informasi, vol. 16, no. 2, pp. 1-6, 2012.

[17] R. S. Pressman, REKAYASA PERANGKAT LUNAK - BUKU SATU, Pendekatan Praktisi ( Edisi 7 ), Yogyakarta: Penerbit ANDI, 2012.

[18] A. Dennis, B. H. Wixom dan D. Tegarden, "Systems Analysis \& Design With UML Version 2.0 An Object-Oriented Approach Third Edition," John Wiley \& Sons, Inc., Hoboken, 2009. 